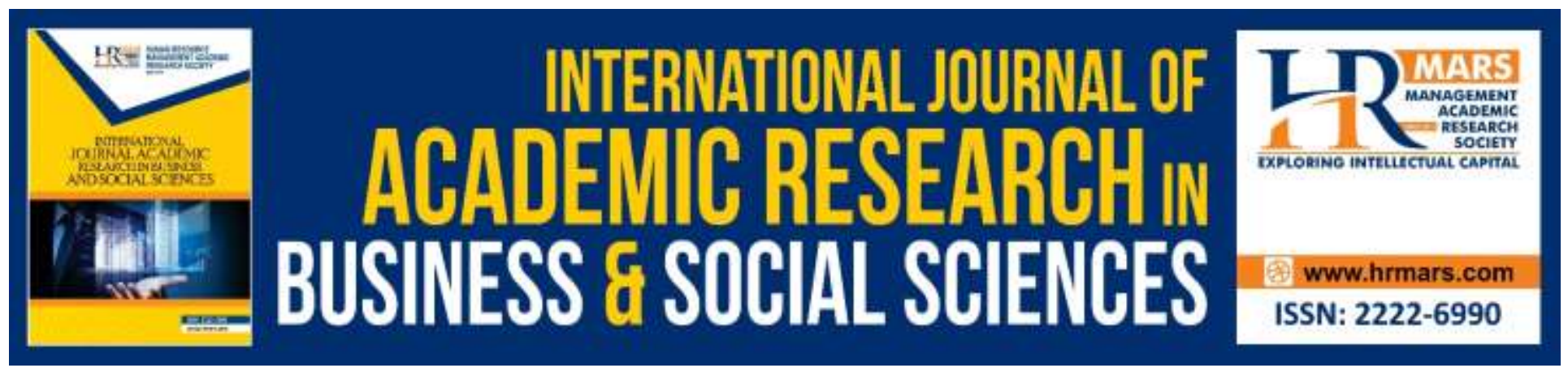

\title{
Workplace Diversity: Emerging Issues in Contemporary Reviews
}

\section{Tamunomiebi, Miebaka Dagogo and John-Eke, Ebere Chika}

To Link this Article: http://dx.doi.org/10.6007/IJARBSS/v10-i2/6926

DOI:10.6007/IJARBSS/v10-i2/6926

Received: 30 December 2019, Revised: 20 January 2020, Accepted: 30 January 2020

Published Online: 13 February 2020

In-Text Citation: (Tamunomiebi \& John-Eke, 2020)

To Cite this Article: Tamunomiebi, M. D., \& John-Eke, E. C. (2020). Workplace Diversity: Emerging Issues in Contemporary Reviews. International Journal of Academic Research in Business and Social Sciences, 10(2), 255-265.

\section{Copyright: (c) 2020 The Author(s)}

Published by Human Resource Management Academic Research Society (www.hrmars.com)

This article is published under the Creative Commons Attribution (CC BY 4.0) license. Anyone may reproduce, distribute, translate and create derivative works of this article (for both commercial and non-commercial purposes), subject to full attribution to the original publication and authors. The full terms of this license may be seen at: $\underline{\text { http://creativecommons.org/licences/by/4.0/legalcode }}$

Vol. 10, No. 2, 2020, Pg. 255 - 265

Full Terms \& Conditions of access and use can be found at http://hrmars.com/index.php/pages/detail/publication-ethics 


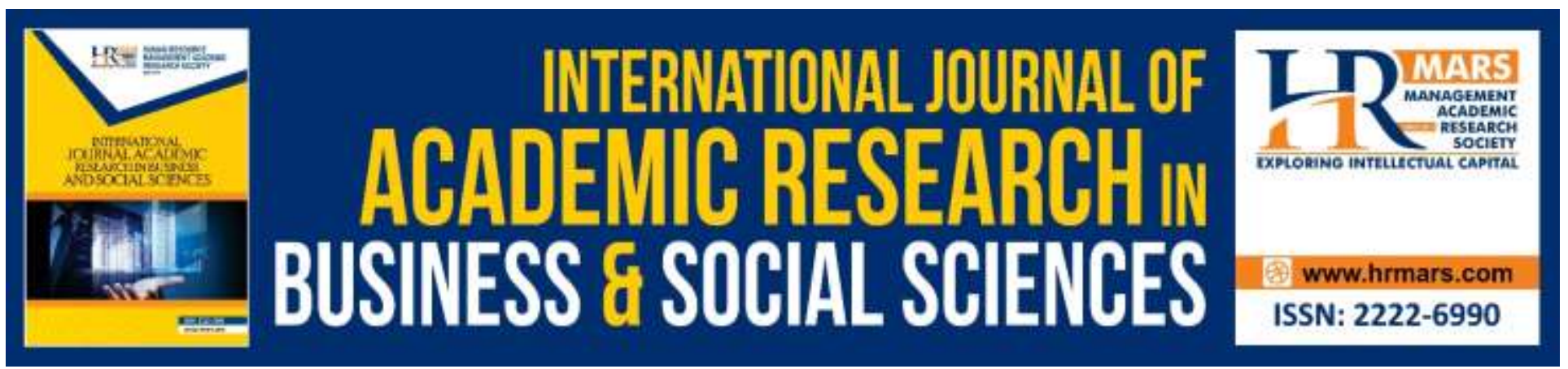

\title{
Workplace Diversity: Emerging Issues in Contemporary Reviews
}

\author{
${ }^{1}$ Tamunomiebi, Miebaka Dagogo PhD and 2John-Eke, Ebere \\ Chika \\ ${ }^{1}$ Department of Management, Faculty of Management Sciences, Rivers, State University, \\ Nkpolu-Oroworukwo, PMB 5080, Port Harcourt, Nigeria, ${ }^{2}$ Doctoral Candidate Department of \\ Management, Faculty of Management Sciences, Rivers State University, Nkpolu-Oroworukwo, \\ PMB 5080, Port Harcourt, Nigeria.
}

\begin{abstract}
This paper is an examination of workplace diversity, especially the emerging issues in contemporary reviews. Considering the demographic differences of people in terms of age, gender, race, ethnicity, culture etc working in an organization that usually drive productivity and business performance; such a diversity or heterogeneous work organization is largely driven by globalization and liberalization of trade which allow productive factor inputs to move freely across nations. Workforce diversity is embedded with some attendant advantages such as the creation of a learning-work environment through collaboration and team participation, productivity and increased profit. It is pertinent to note that, there are some emerging issues in workforce diversity, which include multicultural task environment, existence of large talent pool used for creating and innovation, inter-functional coordination, complexity and discrimination at work. These issues are brought to bear through globalization, migration, aging population, outsourcing, women's work etc. Organization should have a framework for workplace diversity management; optimally allocating resources to create a multicultural engaged workforce for productivity and excellent business performance.
\end{abstract}

Keywords: Workplace Diversity, Discrimination, Globalization, Multicultural, Inter-functional, Team Participation

\section{Introduction}

People are different. They vary in gender, culture, race, social, physical and psychological characteristics. However, our attitudes towards those differences can be negative or positive, depending upon individual perspectives and prejudices. Some characteristics are apparent and others are less obvious (Mavin and Girling, 2000). Greenberg (2004) defines diversity as the variety of differences between people in an organization including race, gender, ethnic group, age, personality, cognitive style, tenure, organizational function, education background and more. According to Fredman (2001), diversity is a recognizable source of creativity and innovation that can 
INTERNATIONAL JOURNAL OF ACADEMIC RESEARCH IN BUSINESS AND SOCIAL SCIENCES

Vol. 10, No. 2, Feb, 2020, E-ISSN: 2222-6990 @ 2020 HRMARS

provide a basis for competitive advantage. However, diversity can also be a cause of misunderstanding, suspicion and conflict in the workplace that can result in absenteeism, poor quality work, low morale and loss of competitiveness. Diversity should be weaved into the fabric of an organization in order to create a mindset in every manager and employee that will allow them to think consciously about treating one another fairly. Today's labor force is highly diverse. If effectively managed, this diversity can provide the organization with a powerful competitive edge which stimulates creativity and infuses flexibility into the company (Beardwell \& Claydon, 2007). Managing diversity is a concept that recognizes the benefits to be gained from differences. It differs from equal opportunity, which aims at legislating against discrimination, assumes that people should be assimilated into the organization and often relies on affirmative action. Globalization increasingly requires employers to hire minority members with the cultural and language skills to deal with diverse customers (Thomas, 1994).

There are two different sets of issues concerning diversity, namely, the social justice case and the business case. According to Mulholland, Ozbilgin and Worman (2005), the social justice case is that managers have a moral obligation to treat employees with fairness and dignity. This involves ensuring that decisions are made without resorting to prejudice and stereotypes. If decisions are made free from prejudice and stereotyping, then there is a lower risk of any particular group being disadvantaged and therefore less chance of an individual feeling that he or she has been discriminated against. The business case is that fair treatment of employees is good for business because it is a better use of human resources, it leads to a wider customer base, it creates a wider pool of labor for recruitment and it leads to a positive company image. However, there may be instances when 'good business sense' provides the justification for not acting in the interest of particular groups. According to Torrington, Hall, \& Stephen (2008) line managers often justify the decision not to employ disabled people on the grounds that the necessary workplace adjustments would eat into their operating budgets. They add that equality and diversity initiatives often have a cost associated with them, the recovery of which cannot always be easily measured and might only be realized in the long term.

Scholars have asserted that most organizations operating in different sectors or industries of an economy are diversified, this position is supported by Stoner, Freeman \& Gilbert (2013), when they posited that, the organization is made up of people with differences in age, gender, ethnicity, culture, nationalities etc. The workplace is diverse in terms of departments, divisions and subsidiaries domiciled in different locations or regions. These dimensions of diversities are as a result of globalization and liberalization of trade, making most organization or institutions as global businesses (Stoner et al., 2013). Hence, most global brands or multi-nationals are characterized with workplace diversity due to changes in the business environment; businesses are more global (Swinton, 2014).

Workplace diversity or organizational diversity is the difference and similarity existing among employees in terms of age, gender, ethnicity, culture, religion, nationalities etc. It also encompasses the differences existing in firm's departments, divisions and subsidiaries domiciled in different regions or nations. According to Dike (2013), workplace diversity can be defined as recognizing, understanding and accepting the individual differences irrespective of their race, gender, age, class, 
ethnicity, physical ability, sexual orientation, spiritual practice etc. Literature has shown that there are two streams of diversity at work; the first stream or dimension include age, gender, sexual orientation etc, while the second stream or dimension includes religion, education, geographical location, income etc (Dike, 2013; Cletus, Mahmood, Umar \& Ibrahim, 2018). It is important to note that workplace diversity is a holistic construct which denotes the differences that exist between people working within an organization. It explains the complex physical, sociological or psychological attributes such as gender, ethnicity, sexual orientation, religion, political beliefs that define an individual or group at work (Cletus et al.,2018).

Workplace diversity has inherent advantages; it helps people to work in synergy. Scholars have viewed the diversity of workforce as strength and organizations can leverage on such strength. This includes talent pool, cross fertilization of knowledge and ideas utilized for productivity (Swinton, 2014), this, creates knowledge based organizations, promotes creativity and improves decision making effectiveness and superior business performance, therefore culturally diverse talent pool at work contribute to innovation and creativity which drives productivity within the firms (Okoro \& Washington, 2012).

Most organizations adopt workplace diversity in order to gain competitive advantage by becoming more creative, adaptive and open to change in a dynamic and ever-changing competitive environment, hence, workplace diversity is important to organizational leaders due to the dynamics of the business environment. As stated by Marzuli, (2012) and Dike, (2013), managing diversity at work by top echelon management is still a challenge, management tend to learn the managerial competences needed in a multicultural working space and prepares themselves to teach others within their organizations to value differences in cultures and treat all workers with respect and dignity. Diversity management is a process intended by workplace leaders to create and maintain a positive working environment where the similarities and differences of employees are valued (Patrick \& Kumar, 2012; Patrick, 2010; Ozbilgin \& Tatli, 2014).

Patrick \& Kumar (2012), posited that diversity includes acceptance and respect; it helps to understand each employee's unique difference which could be along the line of race, ethnicity, gender, sexual orientation, socio-economic status, age, physical abilities, religious and political beliefs or other ideologies. Managing diversity is laudable as it assists organizations to tap the creative, cultural and communicative potentials of a variety of workers and to use these skills to improve organization policies, products and customer experiences.

\section{Literature Review \\ Workplace Diversity}

The $21^{\text {st }}$ century business environment is highly dynamic and ever changing, these changes are largely due to globalization and liberalization of trade and business which has altered the face of business including the composition of employees in the workplace (Udin, Wahyudi \& Wikaningrum, 2017). Hence, the belief that globalization and liberalization of trade has created a diverse workforce in most industries and sectors in terms of age, gender, race, ethnicity, profession, religion etc. Udin et al., (2017), see workplace diversity as the difference that exist in an organization's employee mix in terms 
INTERNATIONAL JOURNAL OF ACADEMIC RESEARCH IN BUSINESS AND SOCIAL SCIENCES Vol. 10, No. 2, Feb, 2020, E-ISSN: 2222-6990 @ 2020 HRMARS

of age, gender, race, ethnicity, sexual orientation, religion, social class, education, national origin, language, skills and professions. Most scholars and researchers have compartmentalized diversity into blocks, usually four main fields which are, personality, internal characteristics of diversity, external characteristics of workplace and organizational characteristics of workplace diversity. Personality capture dimensions such as traits, skills and abilities, internal characteristics of diversity include sub-variables as gender, race, ethnicity, intelligence, and sexual orientation, the external characteristics of workplace diversity hinges on culture, nationality, religion, marital status or elderly and the organizational characteristics of workplace diversity talks about, position, department and union (Chitra \& Chandra, 2017; Singal, 2014).

The dimension of workplace diversity and their relative sub-variables are expected to promote multicultural work environment, promote productivity, professionalism and bring about enhanced organizational performance (Handayani, 2017). Diversity leads to synergy among the different skills and competences inherent in the organization, this tends to encourage collaborative work situation, drive productivity and lead to excellent business performance. Singal (2014), argued that workplace diversity is able to foster creativity and innovation in the firm which provide superior value for customers for competitive advantage and profit growth.

Scholarly literature has shown that workplace diversity helped most organizations and institutions by driving positive success to the firm. However, the complexity of workplace diversity is part of the challenging issues of critical dimensions of firm management. Diversity enhances the critical thinking abilities, problem solving, employee knowledge and professional skills. Furthermore, it enables the enterprise to attract critical talents, improve organizational attractiveness and productivity. Diversity is hampered by organizational incivility and discrimination employees face (Cletus et al., 2018). Meting out this sort of treatment on employees can stifle morale, team building, profit growth and attractiveness of the workplace (John-Eke \& Gabriel, 2019). The institution must deal with these challenges in order to exploit or capitalize on the gains of workplace diversity. The organization should build effective communication and team building at work, build a common community etc, this will drive acceptance, productivity and potential profit growth (Amaliyah, 2015; Dhuppar, 2015; Ashe \& Nazroo, 2017).

The growth in globalization has increased the multicultural nature of the workplace. As nations open up their economies for trade and commerce coupled with the spate of international diversification, which has led to an increase in the number of cultures, beliefs, races, ethnicity, background etc, associated with organizational members at work (Mazur, 2010). People in the workplace no longer live and work in an isolated marketplace environment. They are part of the worldwide economy with global competition from all parts of the continent. This globalization and its attendant global competition can be responded to by building diversity cultures by organizations. This will make the institutions more creative, open and responsive to change. It is therefore imperative for companies to maximize and capitalize on workplace diversity for greater gain and workplace success.

Workplace diversity brings about a complex workforce that is reflective of a changing world and marketplace. In a multicultural, multi-talented and integrated workforce, the organization enjoys 
INTERNATIONAL JOURNAL OF ACADEMIC RESEARCH IN BUSINESS AND SOCIAL SCIENCES Vol. 10, No. 2, Feb, 2020, E-ISSN: 2222-6990 @ 2020 HRMARS

consistently high value, through productivity and competitive advantages (Mazur, 2010). Thus, diversity management in the workplace benefits all organizational members through fair and safe environment where everyone has access to the same opportunities and challenges. Management tools in a diversified workforce should be used to educate all employees on diversity and its attendant issues, including laws and regulations. Today most institutions are made up of diversified cultures, talents/skills, sexual orientations, age, gender etc. Companies must adapt to this emerging workplace issues in order to succeed and earn above average returns.

The study carried out by Choi and Rainey (2010) focused on the effects of diversity and diversity management on employee perceptions of organizational performance in U.S. federal agencies, they developed three measures: diversity, diversity management, and perceived organizational performance. They measured and analyzed levels of diversity of 67 federal agencies to ascertain diversity management affects the relationship between levels of diversity and perceptions of organizational performance. Based on the Central Personnel Data file and the 2004 Federal Human Capital Survey, findings suggest that racial diversity affects organizational performance negatively. Their study also showed that managerial efforts and other contextual factors such as organization culture, demographic characteristics of employees moderate the relationship between diversity and organizational outcomes, whose findings show that the effects of diversity may differ based on types of diversity.

Yaghi and Yaghi (2013) in their empirical work on human resource diversity domiciled in the United Arab Emirates. They analyzed 795 employees in 17 public private sector organizations in the UAE between February 2011 and March 2012. Their findings shows that perception of human resource diversity in the UAE differ by educational level, nationality, employees' gender, job level, professional experience, second language capability and previous experiences gained at various workplace. They were able to develop four factor models, which can be utilized to improve diversity practices in organizations through proper analysis of employees' responses.

Similarly, related work done by Dike (2013) he explored how companies manage workforce diversity and its consequences to the company's existence; he also examined how companies' deal with challenges that accompany employees from various cultural backgrounds. The research tried to examine how workplace diversity contributes to organizational success; owing to the fact that diversity involves various human qualities and attributes, the research mainly focused on tools for managing workplace diversity, advantages and disadvantages of managing various workforce. The research which used qualitative method to gather and analyze the data was carried out in two countries, Finland and Ghana. The work revealed that workplace diversity significantly impact on organizations. Though, there is need for regular improvement to adequately manage various workforce because of the rapidly globalization of the universe.

In a study conducted by Preeti, Poonam and Gupta (2014) titled 'Workforce Diversity Management: Biggest Challenge or Opportunity For 21st Century Organizations', they emphasized that management is a social discipline that deals with people's behaviour and human disposition. Thus, workforce diversity is seen as the biggest challenge as well as the biggest opportunity for the 21st 
INTERNATIONAL JOURNAL OF ACADEMIC RESEARCH IN BUSINESS AND SOCIAL SCIENCES Vol. 10, No. 2, Feb, 2020, E-ISSN: 2222-6990 @ 2020 HRMARS

century managers. Diversity Management is a strategy fashioned to encourage the acknowledgement and implementation of diversity in organizations. The study which was conducted to explore how enterprise manage workforce diversity and its consequences to the organization's existence as well as examine how enterprises deal with challenges that come with employees from diverse cultural backgrounds. They elucidate that workforce diversity has significant relationship with organization performance.

\section{Importance of Workplace Diversity}

Workplace diversity comes with laudable advantages for a company, an industry and an economy. Diversified workforce is a way of contending with labor market volatility, increasing capabilities and competences of organizations in order to achieve superior advantages in the market (Stoner et al., 2013). A diversified workplace brings together talent pool from around the world noted to possess the best skills and competences which the organization leverage for competitive advantage in the market in order to earn above average returns and profitability (Mazur, 2010; Stoner et al., 2013). One of the ways companies can take advantage of global market opportunities due to globalization and trade liberalization is to build global brands with multicultural, diversified and multi-talented orientations. The organization will leverage on diversities to build strategic business units and overseas subsidiaries because recruitment of diverse employees increases supply of employees and potential applicants which can result to greater choice, superior quality and reduced cost (Niederle, Segal \& Vesterlund, 2013).

The creation of a diversified institution or workplace builds a learning organization. When multitalented teams are brought together in a work organization, it gives room for openness, creativity, innovation and learning across the organization, such learning orientation birth creativity and innovation at work (Amaliyah, 2015; Stockdale \& Crosby, 2010). Workplace diversity tends to improve productivity through effective management of the various issues inherent in the workplace. Benefits usually accrue to the firm and employees if diversified workforce is effectively managed (Amaliyah, 2015). A heterogeneous work environment is usually a strong advantage to management, employees and shareholders.

Workplace diversity could create beneficial impact and inclusion within the organization. Some of the associated benefits include cost reduction, improved resources of talented employees, superior products and services, enhance company image, improved firm's creativity and problem solving, objective decision making, innovativeness and innovation, greater flexibility, improved productivity, upscale corporate performance and efficiency, enhanced trust in relationships, improve worker commitment and satisfaction, enhanced customer relationship management and effective service delivery to all the firm's stakeholders (Rohwerder, 2017; Amaliyah, 2015).

Heterogeneous or diversified organization is important to all employees of the firm. The cross fertilization and exchange of ideas and knowledge is largely inherent in a diversified company. This is due to the varied or relative cultures of workers, friendship development and collaborative work behaviour without discrimination (Foma, 2014; Buckingham, 2009; Devah \& Hana, 2008). Employees 
INTERNATIONAL JOURNAL OF ACADEMIC RESEARCH IN BUSINESS AND SOCIAL SCIENCES Vol. 10, No. 2, Feb, 2020, E-ISSN: 2222-6990 @ 2020 HRMARS

learn to cope with the diversified working space, elimination of stereotype and because of healthy competition there is high employee engagement and retention.

Workplace diversity is very prominent for most businesses. It is important that firm's leaders put in place diversity hiring style due to its benefits. Even with the obvious limitations of workplace diversity, the advantages of heterogeneous work environment quiet outweigh the disadvantages. Globalization is spreading like wildfire, and so companies should create a diversified or multicultural working environment and maintain a diversity management plan that fit the firm's unique needs and requirements (Buckingham, 2009; Devah \& Hana, 2008). This is one of the ways modern organizations can cope in a globalized competitive business landscape.

\section{Emerging Issues in Workplace Diversity}

As markets around the world are fast becoming globalized, resources are moving in and out of various industries and sectors, this situation naturally force institution to maintain a diverse workforce with different management style to cope with the emerging issues associated with diversity at work (Foma, 2014; Dike, 2013; Rohwerder, 2017). Emerging issues in workplace diversity include multicultural task environment, development of a large talent pool, inter-functional coordination productivity, complexity, racial discrimination, high cost of diversity management, communication challenges, gender equality management, etc (Wambui, Wangombe, Muthura, Kamau and Jackson, 2013; Gupta, 2013). The above socio-cultural issues are fueled by globalization, migration, aging population, outsourcing, women's work etc. Thus, workplace diversity is organization's adaptation to changing world and market place.

Diversity at work crops up multicultural work environment where people from different cultural background are seen working together in a company. These help employees to learn from the experience of multi-cultures. Workers give respect to their cultural differences while they build on their cultural commonalities. Multicultural workforce utilizes greater participation and synergy to improve employee engagement and company performance (Gupta, 2013). The presence of this diverse culture creates a large talent pool in the organization. There is the growth of diverse skills, talents and competences which the organization leverages for productivity and performance. Diversity brings the best talents around the world to the workplace for productivity and business performance (Mollel, Mulongo \& Maket, 2015).

Another evolving issue in workplace diversity is the inter-functional collaboration and coordination among work departments, strategic business units and subsidiaries. This cross functional team work in synergy and bring about growth in productivity and business performance (Stoner et al., 2013). High productivity and performance are usually associated to diversified organizations relative to a more homogenous workplace. Apart from the emergence of these outlined attributes, there are challenges associated with workplace diversity which include racial discrimination, high cost of diversity management, communication challenges etc.

In most workplaces that are diversified, if the differences among employees are not well managed, discrimination among staff many arise. Racial discrimination is an emerging challenge associated with workforce diversity. Most times top management discriminate against employees who are not 
of the same ethnic background, this negatively affect employee engagement at work (Ogbonna \& Jerry, 2018). Discrimination at work will affect the morale of victim staff, and negatively affect productivity and performance. The company should be able to manage diversity without discrimination, build bridges etc. However, a salient issue that emerges in diversity management is the high cost of management of workforce diversity. This should be optimally done with clear communication and interpersonal relationship among employees. The management of the company should develop a framework for optimal management of workforce diversity.

\section{Conclusion}

Globalization and trade liberalization which has enhanced the mobility of factors of production from one nation to another easier has created a global market with most organizations speedily becoming diversified. Most workplaces are now heterogeneous rather than homogenous and having difference in people in terms of age, gender, ethnicity, culture, skills, profession etc, working in the same organization. Such workforce diversity helps in creating a learning organization through cross fertilization of ideas and knowledge.

Workforce diversity brings about higher productivity and business performance in the workplace as people skills and competences are synergistically brought together for optimal performance of the firm. The emerging issues in workplace diversity are the emergence of a learning organization through integration of talent pool, higher productivity, communication, relationship building and multicultural work orientation. However, some emerging negatives are racial discrimination, high cost of diversity management, gender issues.

The contribution of this study is that it would help the management of organizations to gain perspective on how diversity would impact performance in terms of the quality and efficiency of service delivery. This would guide the human resource department on how to create a good balance so as to encourage diversity. Not only would this be used as a guide in the recruitment process but it can also be used by managers to determine how to form or select diverse teams to work in different organizations.

\section{Recommendations}

There are several ways diversity at work can be managed; organizations should implement the following when managing differences at work. The firm's leadership should learn to value and respect fundamental differences at work, admitting to one's own biases and prejudices and resolving to reduce them, building relationships with diverse others, treating diverse others as invited guests by showing interest in them rather than treating them as stranger. The management should encourage employees to learn languages and cultural differences encourage inclusive work environment and encouraging workers to accept overseas assignment etc (Patrick \& Kumar, 2012; Cletus et al., 2018). In the face of globalization and trade liberalization markets cannot be resistant to diversity. Companies should embrace heterogeneous workforce which will bring about higher productivity and sustainable business performance. Thus, irrespective of the challenges workplace diversity may face, its advantages outweigh the limitations, workplace diversity is a laudable 
INTERNATIONAL JOURNAL OF ACADEMIC RESEARCH IN BUSINESS AND SOCIAL SCIENCES

Vol. 10, No. 2, Feb, 2020, E-ISSN: 2222-6990 @ 2020 HRMARS

predictor of company innovativeness and performance; therefore, top management should effectively manage diversity to bring about workplace harmony.

\section{References}

Amaliyah, A. (2015). The importance of workplace diversity management. International Journal of Sciences. i, 17(2), 175-182.

Ashe, S., \& Nazroo, J. (2017). Equality, diversity and racism in the workplace: A qualitative analysis of the 2015 race at work survey.

Beardwell J., \& Claydon, T. (2007). Human Resource Management - A Contemporary Approach. Prentice Hall, Essex

Buckingham, D. E. (2009). A case study exploring the impact of managing workplace diversity awareness and employee job satisfaction. Retrieved online at http://www.sibresearch.org $12 / 10 / 2019$.

Chitra, K. N., \& Chandra, M. A. (2017). Organizational culture and its influence on workplace diversity and inclusion. International Journal of Civil Engineering and Technology, 8(8), 1032-1038.

Choi, S., \& Rainey, H. G. (2010). Managing diversity in US federal agencies: Effects of diversity and diversity management on employee perceptions of organizational performance. Public Administration Review, 70(1), 109-121.

Cletus, H. E., Mahmood, N. A., Umar, A., \& Ibrahim, A. D. (2018). Prospect and challenges of workplace diversity in modern day organization: A critical review. Holistica, 9 (2), 35-52.

Devah, P., \& Hana, S. (2008). The sociology of discrimination: Racial discrimination in employment, housing, credit and consumer markets. Retrieved online at http://www.princetion.edu 12/10/2019.

Dhupper, S. (2015). Managing workplace diversity challenges and strategies. International Journal of Research, 2(3), 346-351.

Dike, P. (2013). The impact of workplace diversity on organizations. Ph.D Thesis, Arcada University of Applied Sciences, Finland.

Foma, E. (2014). Impact of workplace diversity. Review of Integrative Business and Economics Research, 3(1), 382-389.

Fredman, S. (2001). Equality a new generation? Industrial Law Journal, 30(2)

Gupta, R. (2013). Workforce diversity and organizational performance. International Journal of Business and Management Invention, 2(6), 36-40.

Greenberg, J. (2004). Workplace Diversity: Benefits, Challenges and Solution. Alphameasure Inc. Retrieved from http://www.alphameasure.com

Handayani, S. (2017). Managing workplace diversity for sustaining organizational competitive advantage: A review of literature in proceedings of the $4^{\text {th }}$ Sebelas Maret International conference on business. Economics and Social Sciences, 14(5),140-159.

John-Eke, E. C., \& Gabriel, J. M. O. (2019). Corporate incivility and employee engagement. West African Journal of Business, 13(1), 1595-3750.

Marzuli, J. (2012). Cokes not it: Sixteen workers sue, callgiant Gesspool of racial discrimination. Retrieved online at http://www.nydailynews.com 12/09/2019.

Mazur, B. (2010). Cultural diversity in organizational theory and practice. Journal of Intercultural Management, 2(2), 5-14. 
INTERNATIONAL JOURNAL OF ACADEMIC RESEARCH IN BUSINESS AND SOCIAL SCIENCES Vol. 10, No. 2, Feb, 2020, E-ISSN: 2222-6990 @ 2020 HRMARS

Mollel, E. R., Mulongo, L. S., \& Maket, L. (2015). Workforce diversity management and global organizational growth in the $21^{\text {st }}$ century. Journal of Scientific Research and Studies, 2(7), 164174.

Mavin, S., \& Girling, G. (2000). What is managing diversity and why does it matter? Human Resource Development International, 3(4)

Mulholland, G., Ozbilgin, M., \& Worman, D. (2005). Managing Diversity - Linking Theory and Practice to Business Performance. London: CIPD.

Niederle, M., Segal, C., \& Vesterlund, L. (2013). How costly is diversity? Affirmative action in light of gender differences in competitiveness. Management Science, 59(1), 1-16.

Ogbonna, S. A., \& Jerry, E. E. (2018). Workforce diversity management in Nigeria public service: Problems and prospects. Global Journal of Human Resources Management, 6(1), 35-47.

Okoro, E. A., \& Washington, M. C. (2012). Workforce diversity and organizational communication: Analysis of human capital performance and productivity. Journal of Diversity Management, 17 (7), 42-59.

Ozbilgin, M., \& Tatli, A. (2011). Global Diversity Management: An evidence based approach. London: Palgrave.

Patrick, H. A., \& Kumar, V. R. (2012). Managing workplace diversity: Issues and challenges. Retrieved online at http://www.sgo.sagepub.com 12/09/19.

Patrick, H. A. (2010). Organization culture and its impact on diversity openness in the information technology organizational context. Dimensions, 1 (1), 67-72.

Preeti, M., Poonan, T., \& Gupta, E. (2014). Workforce diversity management: Biggest challenge or opportunity for 21st century organizations. Journal of Business and Management, 16(3), 102107.

Rohwerder, B. (2017). Diversity and inclusion within organizations. K4D helpdesk report. Brighton, UK: Institute of development and studies.

Sigal, M. (2014). The business case for diversity management in the hospitality industry. International Journal of Hospitality Management, 40(12), 10-19.

Stoner, J. A. F., Freeman, R. E., \& Gilbert, D. R. (2013). Management, Sixth Edition. NewDelhi: Dorling Kindersley Limited.

Swinton, W. H. (2014). Diversity in the workforce. Journal of Education and Human Development, $3(4), 73-82$.

Thomas, R. R. (Ed) (1994). Differences that Work: Organizational Excellence through Diversity. A Harvard Business Review Book. Boston: HBS.

Torrington, D., Hall, L. \& Stephen, T. (2008). Human Resource Management. Harlow: Prentice Hall

Udin, S. H., Wahyudi, S. A.Y. S., \& Wikaningrum, T. (2017). A systematic literature review of managing workplace diversity for sustaining organizational competitive advantage. International Journal of Mechanical Engineering and Technology, 8(12), 398-403.

Wambui, T. W., Wangombe, J. G., Muthura, M. W., Kamau, A. W., \& Jackson, S. M. (2013). Managing workplace diversity: A Keyan perspective. International Journal of Business and Social Science, 4(16), 199-216.

Yaghi, A., \& Yaghi, I. (2013). Human resource diversity in the United Arab Emirates: Empirical study. Education, Business and Society. Contemporary Middle Eastern Issues, 6(1), 15-30. 